\section{The Creation of the} Euro and the Role of the Dollar in International Markets

\author{
Patricia S. Pollard
}

D uring the nineteenth and the first half of the twentieth centuries, the British pound was the preeminent international currency. It was used in both international trade and financial transactions and circulated throughout the British empire. With the decline of British economic power in the 20th century, the U.S. dollar replaced the pound as the leading international currency. For over 50 years the U.S. dollar has been the leading currency used in international trade and debt contracts. Primary commodities are generally priced in dollars on world exchanges. Central banks and governments hold the bulk of their foreign exchange reserves in dollars. In addition, in some countries dollars are accepted for making transactions as readily as (if not more so than) the domestic currency.

On January 1, 1999, a new currency-the eurowas created, culminating the progress toward economic and monetary union in Europe. The euro replaced the currencies of 11 European countries: Austria, Belgium, Finland, France, Germany, Ireland, Italy, Luxembourg, the Netherlands, Portugal, and Spain. ${ }^{1}$ Two years later Greece became the 12 th member of the euro area.

Although the Japanese yen and particularly the German mark have been used internationally in the past several decades, neither currency approached the international use of the dollar. With the creation of the euro, for the first time the dollar has a potential rival for the status as the primary international currency. What changes in the international use of the dollar have occurred in the first two years of the euro's existence? What changes are likely over the next decade? Moreover, what are the implications for the United States and the euro area as a result of these changes? To answer these questions, this article begins with an overview of the functions of

Patricia S. Pollard is a research officer and economist at the Federal Reserve Bank of St. Louis. Heidi L. Beyer provided research assistance. an international currency and the major factors that determine whether a currency will be used outside its borders. It then examines the use of currencies in international markets prior to the establishment of the euro and the changes brought about by the creation of the euro. ${ }^{2}$

\section{FUNCTIONS OF AN INTERNATIONAL CURRENCY}

Economists define money as anything that serves the following three functions: a unit of account, a store of value, and a medium of exchange. To operate as a unit of account, prices must be set in terms of the money. To function as a store of value, the purchasing power of money must be maintained over time. ${ }^{3}$ To function as a medium of exchange, the money must be used for purchasing goods and services. For an international currency, one used as money outside its country of issue, these functions are generally divided by sector of use-private and official, as listed in Table 1.4

A currency serves as a unit of account for private international transactions if it is used as an invoice currency in international trade contracts. It serves as a store of value if international financial assets are denominated in this currency. It serves as a medium of exchange internationally if it is used as a vehicle currency through which two other currencies are traded, and as a substitute for a domestic currency.

A currency serves as a unit of account for official international purposes if it is used as an exchange rate peg. It serves (i) as a store of value if governments and/or central banks hold foreign exchange

1 Although the national currencies will continue to exist until 2002 , they are merely subunits of the euro.

2 Between the time that the Treaty on European Union established the process for the completion of economic and monetary union and the creation of the euro, many economists studied the likely international role of the euro. Among these are Bekx (1998), Bénassy-Quéré, Mojon, and Schor (1998), Bergsten (1997), Hartmann (1996), Johnson (1994), Kenen (1993), Pollard (1998), and Portes and Ray (1998). Most of these studies concluded that the euro would be a major international currency but that the process would be gradual. Bergsten and Portes and Ray, however, expected a quick ascent for the euro.

3 This is the most difficult role for currency to achieve. Inflation reduces the purchasing power of money. As long as inflation is moderate, the ability of money to operate as a unit of account and medium of exchange ensure its continued use. Hyperinflation causes money to lose its store of value function and is associated with an increase in the use of barter and substitute currencies.

4 This sectoral division of the three functions of international money was first adopted by Cohen (1971). 
Table 1

\section{Functions of an International Currency}

\begin{tabular}{llc} 
& & Sector \\
\cline { 2 - 3 } Function & \multicolumn{1}{c}{ Private } & Official \\
\hline Unit of account & Invoice & Exchange rate peg \\
Store of value & Financial assets & Reserves \\
Medium of exchange & Vehicle/substitution & Intervention \\
\hline
\end{tabular}

reserves in this currency and (ii) as a medium of exchange if it is used for intervening in currency markets.

The three functions of an international currency reinforce each other. For example, the use of a currency for invoicing trade and holding financial assets increases the likelihood that the currency will be used as a vehicle currency. In the official sector, if a country pegs its exchange rate to another currency, it is likely to hold reserves in that currency and conduct its interventions in exchange markets in that currency. In addition, the use of an international currency by one sector reinforces its use by the other sector. For example, using a currency as an exchange rate peg facilitates the use of that currency in debt contracts and foreign trade.

\section{DETERMINANTS OF AN INTERNATIONAL CURRENCY}

What determines the likelihood that a currency will be used in the international exchange of goods, services, and assets? Five key factors are as follows:

- Size of the economy

- Importance in international trade

- Size, depth, liquidity, and openness of domestic financial markets

- Convertibility of the currency

- Macroeconomic policies

The size of a country's economy is important because it determines the potential use of the currency in international markets. Economic size is linked with the importance of a country in international trade and the size of its financial markets. For example, exports account for a much greater share of the output of the Korean economy than for the U.S. economy. Nevertheless, because the U.S. economy is nearly 14 times larger than the
Korean economy, U.S. exports comprise a much larger share of world exports.

Clearly the dominance of the U.S. economy and the decline of the U.K. economy in the twentieth century were related to the rise of the dollar and the decline of the pound as international currencies. Likewise, the growth of the German and Japanese economies in the last several decades of the twentieth century prompted the use of their currencies in international markets. As a result, the overwhelming dominance the dollar held in international markets in the 1950s and 1960s diminished.

Table 2 compares the relative size of the U.S., euro-area, and Japanese economies. The U.S. economy is the largest in the world, accounting for about 22 percent of world output. The establishment of economic and monetary union in Europe, linked through the euro, has created the world's second largest economy. The Japanese economy is less than half the size of the euro area. ${ }^{5}$

The share of a country in international trade as well as the size and openness of its financial markets are determinants of the demand for that country's currency in world markets. The United States accounts for a lower share of world exports than does the current euro area, as shown in Table 2. The size of U.S. financial markets as measured by the sum of bank assets, outstanding domestic debt securities, and stock market capitalization, however, is much larger than in the euro area. Japan is a distant third in terms of its share of world exports, but its financial markets are close in size to those in the euro area.

The convertibility of a country's currency is another important determinant of its use in international markets. Restrictions on the ability to

\footnotetext{
5 In 1994 the Chinese economy surpassed the size of the Japanese economy. Based on purchasing power parity valuations of GDP, China accounted for 11.2 percent of the world's output in 1999. Nevertheless, Japan remains the world's third major economic power.
} 


\section{Table 2}

\section{Comparison of United States, Euro-Area, and Japanese Economies in 1999}

\begin{tabular}{lrrr} 
& United States & Euro area & Japan \\
\hline Share of world GDP (\%) & 21.9 & 15.8 & 7.6 \\
Share of world exports (\%) & 15.3 & 19.4 & 9.3 \\
Financial markets (\$ billions) & $40,543.8$ & $24,133.4$ & $20,888.5$ \\
$\quad$ Bank assets (\$ billions) & $7,555.3$ & $12,731.3$ & $6,662.5$ \\
$\quad$ Domestic debt securities outstanding (\$ billions) & $15,426.3$ & $5,521.9$ & $6,444.9$ \\
$\quad$ Stock market capitalization (\$ billions) & $17,562.2$ & $5,880.2$ & $7,781.4$
\end{tabular}

NOTE: GDP is based on purchasing power parity equivalents. World exports excludes intra-euro-area trade.

SOURCE: GDP: IMF, World Economic Outlook, October 2000. Exports: IMF, Direction of Trade Statistics Quarterly, September 2000. Bank assets: European Central Bank, Monthly Bulletin; Board of Governors of the Federal Reserve System, Flow of Funds Accounts; IMF, International Financial Statistics. Debt securities: Bank for International Settlements, Quarterly Review of International Banking and Financial Market Developments. Stock market: Eurostat.

exchange a currency for other currencies limits its global use. At the end of World War II almost every country, with the exception of the United States, restricted the convertibility of its currency. This inconvertibility persisted for the first decade after the war. The convertibility of the U.S. dollar prompted its use as the currency in which international trade was conducted.

Macroeconomic policies also play an important role in determining whether a country's currency will be used internationally. These policies affect a country's economic growth and its openness to the world economy. Policies fostering a low inflation environment are especially important. Countries experiencing hyperinflation and/or political crises often see the use of their currencies collapse not only internationally but also within the domestic economy, as residents turn to a substitute currency.

Clearly the size and openness of the U.S. economy have been major factors in encouraging the international use of the dollar in the post-World War II period. Its use as an international currency in the private sector and the effect of the emergence of the euro in this sector is examined in the next section.

\section{THE PRIVATE USES OF AN INTERNATIONAL CURRENCY}

As stated above, a currency operates as an international currency in the private sector (i) if international trade and debt contracts are priced in this currency; (ii) if this currency is used to facilitate the exchange of other currencies; and (iii) if this currency is used as a substitute currency.

\section{Invoice Currency}

The dollar is the main currency that functions as a unit of account for private international transactions. Although data on the currency of invoice in international trade are limited, the available data confirm the dominance of the dollar. In 1995 the U.S. dollar was used as the invoice currency for more than half of world exports, down only slightly from 1980 , as shown in Table 3. The Deutsche mark was the next most popular invoice currency, used for approximately 13 percent of world exports, followed by the French franc and the British pound. While the yen's use in world trade lagged behind these European currencies, its share had more than doubled since 1980. The combined share of the four major euro currencies was less than half that of the U.S. dollar.

More importantly, there is a clear distinction between the use of the dollar and other invoice currencies. The U.S. dollar is the only currency whose use in world trade far surpasses its country share in world trade, as shown by its internationalization ratio in Table 3. An internationalization ratio less than 1.0, as with the yen, lira, and guilder, indicates that not all of that country's exports are denominated in the local currency. An internationalization ratio greater than 1.0 , as with the dollar, the mark, and the pound, indicates that other coun- 


\section{Table 3}

\section{Trade Invoiced in Major Currencies}

\begin{tabular}{|c|c|c|c|c|}
\hline \multirow[b]{2}{*}{ Currency } & \multicolumn{2}{|c|}{ Percent of world exports } & \multicolumn{2}{|c|}{ Internationalization ratio } \\
\hline & 1980 & 1995 & 1980 & 1995 \\
\hline U.S. dollar & 56.4 & 52.0 & 4.5 & 3.9 \\
\hline Japanese yen & 2.1 & 4.7 & 0.3 & 0.6 \\
\hline Deutsche mark & 13.6 & 13.2 & 1.4 & 1.4 \\
\hline French franc & 6.2 & 5.5 & 0.9 & 1.0 \\
\hline British pound & 6.5 & 5.4 & 1.1 & 1.1 \\
\hline Italian lira & 2.2 & 3.3 & 0.5 & 0.8 \\
\hline Netherlands guilder & 2.6 & 2.8 & 0.7 & 0.9 \\
\hline Euro-4 & 24.6 & 24.8 & NA & NA \\
\hline
\end{tabular}

NOTE: Euro-4 is the share of the four euro-area currencies listed in the table. No data were available for the other euro-area currencies. World exports includes intra-euro-area trade. The internationalization ratio is the ratio of the share of world exports denominated in a currency to the share of the issuing country in world exports.

SOURCE: Bekx (1998, Table 3, p. 8).

tries use that currency to invoice some (or all) of their exports. 6

What determines the currency of invoice in world trade? A number of studies including those by Grassman (1973), Page (1981), and Black (1990) revealed the following patterns. Trade in manufactured goods among the industrial economies is most often priced in the currency of the exporter. If the exporter's currency is not used, then the importer's currency is the most frequent choice. Only rarely is a third country's currency used. Trade between industrial and developing countries is generally priced in the currency of the industrial country or that of a third country. Trade between developing countries is often priced in the currency of a third country. When a third country's currency is used for invoicing trade, the U.S. dollar is the most likely choice. Trade in primary commodities is almost always invoiced in U.S. dollars because these products are predominantly priced in dollars on international exchanges.

According to Hartmann (1996), two factors that explain these patterns are transaction costs and acceptability. The lower the cost of buying and selling a currency in the foreign exchange market, the more likely is its use for invoicing trade. In addition, the more accepted a currency is for other transactions, the more likely it is to be used as an invoice currency. Clearly these two factors are mutually supportive. The more accepted a currency is, the lower its transaction costs; the lower its transaction costs, the more likely it is to be accepted.

Related factors that explain these patterns are convertibility and the expected stability of the currency. As noted above, the use of the dollar as an invoice currency was prompted by the lack of convertibility of most other currencies in the 1950s. The limited use of developing countries' currencies in world trade arose in part because many of these countries restricted (and some continue to restrict) the convertibility of their currencies. Black (1990) showed that the share of a country's exports denominated in its domestic currency declines the greater is the expected depreciation of its currency. Thus, the currencies of countries with high inflation are seldom used in international trade.

The mere creation of the euro as a currency should provide ample incentive for its use as an invoice currency. Replacing the currencies of 12 countries with a single currency reduces the transaction costs involved in currency exchanges. Although only a small number of firms within the euro area have already switched to invoicing in euros, the advent of euro notes and coins, along

\footnotetext{
6 An internationalization ratio greater than or equal to 1.0 does not imply that all of the home country's exports are priced in its currency. According to data provided in Bekx (1998) in 1995, 92 percent of U.S exports, 75 percent of German exports, 62 percent of British exports and 52 percent of French exports were invoiced in their domestic currencies.
} 


\section{Table 4}

\section{Volatility of Real Oil Prices in the United States and Germany* (Percent)}

\begin{tabular}{|c|c|c|c|}
\hline Year & Volatility of real U.S. \$ price & Volatility of real DM price & F-test probability ${ }^{\dagger}$ \\
\hline 1985 & 4.5 & 5.7 & 48.8 \\
\hline 1986 & 17.8 & 17.3 & 93.6 \\
\hline 1987 & 5.7 & 5.8 & 96.6 \\
\hline 1988 & 8.2 & 8.1 & 96.3 \\
\hline 1989 & 6.3 & 6.9 & 79.0 \\
\hline 1990 & 18.9 & 17.8 & 84.0 \\
\hline 1991 & 8.6 & 9.5 & 74.8 \\
\hline 1992 & 4.4 & 4.5 & 95.9 \\
\hline 1993 & 4.6 & 4.9 & 85.6 \\
\hline 1994 & 5.4 & 5.2 & 91.3 \\
\hline 1995 & 5.3 & 6.2 & 61.4 \\
\hline 1996 & 6.1 & 6.6 & 80.5 \\
\hline 1997 & 6.8 & 6.3 & 79.4 \\
\hline 1998 & 8.2 & 6.7 & 50.4 \\
\hline 1999 & 9.4 & 10.0 & 84.3 \\
\hline 2000 & 11.6 & 13.4 & 64.2 \\
\hline
\end{tabular}

with the withdrawal from circulation of the notes and coins of the legacy currencies in 2002, will prompt several changes. According to Page (1981), the use of the dollar is negligible in intra-European Union trade, so the creation of the euro should not have had a noticeable effect on invoicing in the region. Where its effect is likely to be largest is in extra-euro-area trade, where most exports are likely to be invoiced in euros. It is unlikely, however, that trade currently invoiced in dollars and involving neither the euro area nor the United States will shift in the near term to euros. This argument is supported by the European Central Bank (ECB), which estimates that the percent of world exports denominated in euros "is likely not to differ significantly from that of euro area exports" (ECB, 1999, p. 36). Thus, the internationalization ratio for the euro area will be close to 1 .

What effects will the use of the euro as an invoice currency have on the euro area and the United States? For firms in the euro area, gains will arise from a reduction in transactions costs and exchange rate risk. In intra-euro-area trade, exchange rate risk has already been eliminated and the transactions costs will be eliminated by 2002. Turning to the external trade of the euro area, the smaller euro-area countries will gain the most from the reduction in transactions costs because, prior to the establishment of the euro, the limited demand for their currencies resulted in higher costs for exchanging their currencies for other currencies. A rise in the share of euro-area external trade invoiced in euros may also reduce the exposure of its businesses to short-term exchange rate variability. To the extent that there is an increase in the use of the euro in trade between the euro area and the United States, the exposure of U.S. businesses to exchange rate risk will rise. The importance of such a change is unclear. There exists a wide range of options to hedge exchange rate risk, but these options are not costless. Magee and Rao (1980), however, argue that the currency of denomination in trade contracts is irrelevant if both the exporter and importer have the same risk preferences; this 


\section{Table 5}

Funds Raised in International Bond Markets by Currency of Issue (Percent)

\begin{tabular}{lccrr} 
Currency & $\mathbf{1 9 5 0 - 5 9}$ & $\mathbf{1 9 6 0 - 6 9}$ & $\mathbf{1 9 7 0 - 7 9}$ & $\mathbf{1 9 8 0 - 8 9}$ \\
\hline U.S. dollar & 78.2 & 69.9 & 49.2 & 50.7 \\
Japanese yen & 0.0 & 0.0 & 5.2 & 8.9 \\
Swiss franc & 7.1 & 5.4 & 17.5 & 11.4 \\
Euro area* $^{\text {Deutsche mark }}$ & 3.2 & 20.3 & 24.1 & 15.8 \\
Other E.U. $^{+}$ & 2.0 & 16.3 & 17.9 & 8.0 \\
$\quad$ Pound sterling & 8.7 & 3.1 & 0.7 & 6.8 \\
& 8.3 & 2.9 & 0.6 & 6.4
\end{tabular}

*Euro area includes the currencies of all current members of the euro area and currency composites, such as the ecu.

${ }^{\dagger}$ Other E.U. includes the currencies of Denmark, Greece, Sweden, and the United Kingdom.

SOURCE: OECD, International Capital Market Statistics, 1996, and Financial Statistics Monthly, June 1997.

is so because the contract price should incorporate an exchange rate risk premium.

The dollar is also the main currency used for pricing internationally traded commodities, with the British pound being the only other currency used. As Tavlas (1997) notes, the commodity exchanges on which these products are traded are located in countries "that have a comparative advantage as financial centers," thus explaining the dominance of the United States and the United Kingdom and hence the currency choice.

The creation of the euro is unlikely to lead to any change in the pricing of these commodities. The location of major commodity exchanges in the United States, while not a necessary requirement for dollar pricing, does increase the likelihood that these commodities will continue to be priced in dollars. Although it is possible that an integrated Europe will develop commodity exchanges to rival those of the United States, such a shift is likely to be gradual. Any shift in pricing of these commodities is unlikely to occur until the stability of Europe's new monetary system is well established. ${ }^{7}$

Suppose, however, that there is eventually a shift in the pricing of commodities from dollars to euros. Would such a change increase the volatility of these prices for U.S. consumers while lowering the volatility for euro-area consumers? For this to occur, exchange rate fluctuations must not only introduce another source of volatility into the price of these commodities but must be positively correlated with the price volatility. There is no reason to expect this to hold. An examination of data on the real price of crude oil in U.S. dollars and in Deutsche marks illustrates this point. The real price of oil in the U.S. depends on the dollar price of oil in international markets and the U.S. inflation rate, whereas the real price of oil in Germany depends on the dollar price of oil in international markets, the mark/ dollar (now euro/dollar) exchange rate, and the German inflation rate. Table 4 indicates the yearly volatility of each of these measures from 1985 to 2000. In 3 of the 16 years there was no statistical difference in the volatility of the real dollar price and the real mark price of crude oil. ${ }^{8}$ In 8 of the 16 years the volatility of the real mark price was greater than the volatility of the real dollar price. In the remaining 5 years the volatility of the real dollar price was greater than the volatility of the real mark price. These data do not provide clear support for the idea that having commodities priced in a country's domestic currency on world exchanges results in lower variability in the real domestic-currency price of the commodity.

\section{Financial Assets}

In international bond markets the U.S. dollar was the currency of choice for nearly all issues in

\footnotetext{
7 In October 2000, Iraq began requiring payment for its oil exports in euros. There is no indication that this move will be followed by other major oil producers. A general shift to requiring payment in euros would probably hasten a switch to pricing oil in euros, but such a dual system is not without precedent. Bénassy and Deusy-Fournier (1994) state that until 1974 oil was priced in dollars, but payment was made in pounds sterling.

8 Measured by a 95 percent or higher probability.
} 


\section{Table 6}

\section{International Debt Securities by Currency of Issue (Percent)}

\begin{tabular}{|c|c|c|c|c|c|c|}
\hline \multirow[b]{2}{*}{ Currency } & \multicolumn{3}{|c|}{ Amounts outstanding } & \multicolumn{3}{|c|}{ Share of new issues } \\
\hline & 1993 & 1998 & 2000 & 1998 & 1999 & 2000 \\
\hline \multicolumn{7}{|l|}{ Total securities } \\
\hline U.S. dollar & 41.1 & 45.9 & 48.7 & 54.1 & 45.2 & 44.0 \\
\hline Japanese yen & 13.2 & 11.3 & 8.2 & 5.6 & 5.3 & 8.3 \\
\hline Swiss franc & 7.3 & 3.8 & 2.2 & 3.3 & 2.0 & 1.7 \\
\hline Euro area* & 24.8 & 27.2 & 30.1 & 24.6 & 36.8 & 33.9 \\
\hline Other E.U. ${ }^{+}$ & 7.9 & 8.5 & 8.2 & 8.9 & 8.0 & 9.2 \\
\hline Pound sterling & 7.6 & 7.9 & 7.8 & 8.3 & 7.7 & 9.1 \\
\hline \multicolumn{7}{|l|}{ Bonds and notes } \\
\hline U.S. dollar & 38.9 & 45.3 & 48.7 & 51.1 & 43.8 & 42.3 \\
\hline Japanese yen & 14.0 & 11.7 & 8.6 & 6.3 & 6.7 & 11.4 \\
\hline Swiss franc & 7.7 & 3.8 & 2.2 & 2.7 & 1.6 & 1.4 \\
\hline Euro area* & 25.7 & 27.6 & 30.0 & 28.0 & 38.3 & 34.2 \\
\hline Other E.U. ${ }^{\dagger}$ & 8.1 & 8.5 & 8.1 & 9.0 & 7.3 & 8.4 \\
\hline Pound sterling & 7.8 & 7.9 & 7.7 & 8.2 & 7.0 & 8.2 \\
\hline \multicolumn{7}{|l|}{ Money Market } \\
\hline U.S. dollar & 79.4 & 59.9 & 49.1 & 61.0 & 48.8 & 47.5 \\
\hline Japanese yen & 0.2 & 2.5 & 2.3 & 4.0 & 1.4 & 1.9 \\
\hline Swiss franc & 1.8 & 4.5 & 2.3 & 4.7 & 2.9 & 2.3 \\
\hline Euro area* & 8.5 & 19.2 & 32.4 & 17.2 & 32.9 & 33.2 \\
\hline Other E.U. ${ }^{+}$ & 4.1 & 8.4 & 9.5 & 8.8 & 9.8 & 11.0 \\
\hline Pound sterling & 4.0 & 8.3 & 9.3 & 8.7 & 9.7 & 11.0 \\
\hline
\end{tabular}

*Euro area includes the currencies of the $\mathbf{1 1}$ original members of the euro area and currency composites, such as the ecu.

${ }^{\dagger}$ Other E.U. includes the currencies of Denmark, Sweden, and the United Kingdom.

SOURCE: Bank for International Settlements, Quarterly Review of International Banking and Financial Market Developments, March 2001.

the 1950s. By the 1970s, however, the currency denomination of bond issues had become more diversified, as shown in Table 5. Nevertheless, the U.S. dollar has remained the most popular currency choice for issuing bonds in international markets, as shown in Table 6. ${ }^{9}$ By the 1960 s the euro legacy currencies, taken together as a group, had become the second most widely used currency in international bond markets, a status that continues today. The Japanese yen was not used at all until the 1970s, and its share of new issues lags far below that of the dollar or euro. The use of the Swiss franc in international bond markets, which rivaled the Deutsche mark in the 1970s, declined precipitously in the 1990s. ${ }^{10}$
In international money markets as well, the dollar is the currency of choice, but again its dominance has declined, as noted in Table 6 . The increased use of the euro legacy currencies in these markets during the 1990s is particularly noteworthy. In 1993 these currencies accounted for 8.5 percent of the outstanding debt in international money markets. By 1998 this share had increased to 19.2 percent.

9 The data in Tables 5 and 6 rely on different sources and hence may not be directly comparable.

${ }^{10}$ Some policymakers in Switzerland were concerned that the creation of the euro might result in a sharp rise in demand for assets denominated in Swiss francs. See Laxton and Prasad (1997) for an analysis of this argument. 


\section{Table 7}

Banks' Cross-Border Positions: Amounts Outstanding* (Percent)

\begin{tabular}{|c|c|c|c|c|c|}
\hline Currency & 1983-89 & $1990-99$ & 1998 & 1999 & 2000:Q3 \\
\hline \multicolumn{6}{|l|}{ Assets } \\
\hline U.S. dollar & 59.7 & 47.0 & 45.2 & 45.4 & 47.0 \\
\hline Japanese yen & 10.0 & 12.0 & 11.6 & 10.3 & 9.9 \\
\hline Euro area $^{\dagger}$ & 18.6 & 27.4 & 28.1 & 31.8 & 30.7 \\
\hline Pound sterling & 3.4 & 4.3 & 4.9 & 4.9 & 5.1 \\
\hline \multicolumn{6}{|l|}{ Liabilities } \\
\hline U.S. dollar & 62.4 & 49.3 & 47.6 & 49.9 & 51.9 \\
\hline Japanese yen & 7.9 & 8.0 & 8.4 & 7.8 & 7.4 \\
\hline Euro area $^{+}$ & 17.2 & 26.8 & 26.3 & 26.9 & 25.4 \\
\hline Pound sterling & 4.3 & 5.6 & 6.5 & 6.7 & 6.9 \\
\hline
\end{tabular}

The creation of the euro led to a sharp rise in its use in international debt markets relative to its legacy currencies. The share of new issues of inter national securities denominated in the euro legacy currencies was 24.6 percent in 1998. In the following year, the share denominated in euros was 36.8 percent. Although the use of the euro relative to its legacy currencies rose strongly in both the bond and money market, the increase was highest in the money market. In international debt markets, there is now a clear alternative to the use of the dollar. ${ }^{11}$

In international banking there is also evidence of currency diversification over the last two decades. Table 7 shows the assets and liabilities of banks accounted for by transactions with foreign residents (either in the domestic or foreign currencies). During the 1980s, 60 percent of the cross-border assets of banks were in dollars and 19 percent in the euro legacy currencies. In the 1990s, the dollar's share fell to 47 percent and the euro legacy currencies' share rose to 27 percent. A similar pattern is noted for cross-border liabilities. The advent of the euro, however, has had little initial effect on international banking. The dollar's share of cross-border assets remained nearly constant while its share of crossborder liabilities increased slightly. The opposite pattern held for euros. There was a slight increase in the share of cross-border assets denominated in euros, relative to the euro legacy currencies, and virtually no change in liabilities. ${ }^{12}$
The use of a country's currency in international capital markets is determined by the size, openness, and liquidity of that country's financial markets and the stability of its currency. The decline in the dollar's dominance in world capital markets, prior to the creation of the euro, is a result of the emergence of other strong economies that, in conjunction with the liberalization and deregulation of financial systems worldwide, increased the attractiveness of assets denominated in other currencies. This is particularly evident in the bond markets where there has been a rapid increase in the number of currencies used.

The creation of the euro has spurred changes within euro-area financial markets. Integration has been most evident in the money market. Overnight interbank interest rates have become nearly harmonized throughout the euro area, aided in part by the creation of the TARGET payments system and also by the common monetary policy. ${ }^{13}$ Although the unsecured deposit market has become highly integrated, other aspects of the money market (for

\footnotetext{
11 Kool (2000) addresses the use of the euro in international bond markets.

12 The data in Table 7 do not exclude bank transactions between members of the euro area.

13 TARGET is an acronym for Trans-European Automated Real-time Gross settlement Express Transfer system.
} 
example the repo market and short-term securities market) remain more segregated. ${ }^{14}$

There also has been some progress in the bond market as both the size and integration of the market have increased accompanied by an increase in liquidity in the secondary market. ${ }^{15}$ Although there has been an increase in euro bonds issued by residents outside the euro area, most of the international issues were placed by euro-area residents. ${ }^{16}$ One reason for the sharp increase in the latter issues is that the establishment of the euro reduced barriers to cross-border investment within the euro area. For example, insurance companies and some pension funds within the euro area are restricted in their ability to issue international debt. Liabilities in a foreign currency must be 80 percent matched by assets in that same currency. With the creation of the euro this matching rule becomes less restrictive.

Despite this progress, Santillán et al. (2000) note that the euro-area corporate bond market lags that of the United States with regard to liquidity, size, and market completeness. Indeed the ability of European capital markets to rival those of the United States, at least in the short-term, is not certain. Cecchetti (1999) cautions that differences in legal structures across Europe will limit the degree of integration of financial structures. Kregel (2000) argues that the European monetary union is based on "an internal contradiction which attempts to combine the preservation of the institutional characteristics of national markets with convergence of macroeconomic performance." Thus he states it is not clear that the introduction of the euro will eliminate national segmentation.

This segmentation also exists in the euro-area government bond market. Although differences in yields on government bonds issued by the member states of the euro area have declined in the last several years, complete convergence has not occurred. According to a report by the Bank for International Settlements (BIS) (2000b), these differences are caused not so much by differences in risk but by "technical and liquidity considerations." The report further notes that this lack of integration implies that no euro-area government bond market can serve as a benchmark for the whole euro area and as such there is no "well defined reference government yield curve" that would aid the pricing of euroarea corporate bond issues, among other things.

Figure 1 illustrates these points using long-term government bond yields for four euro-area countries. There was a noticeable convergence in yields as

\section{Figure 1}

\section{Government Bond Yields}

Monthly data, various euro-a rea countries

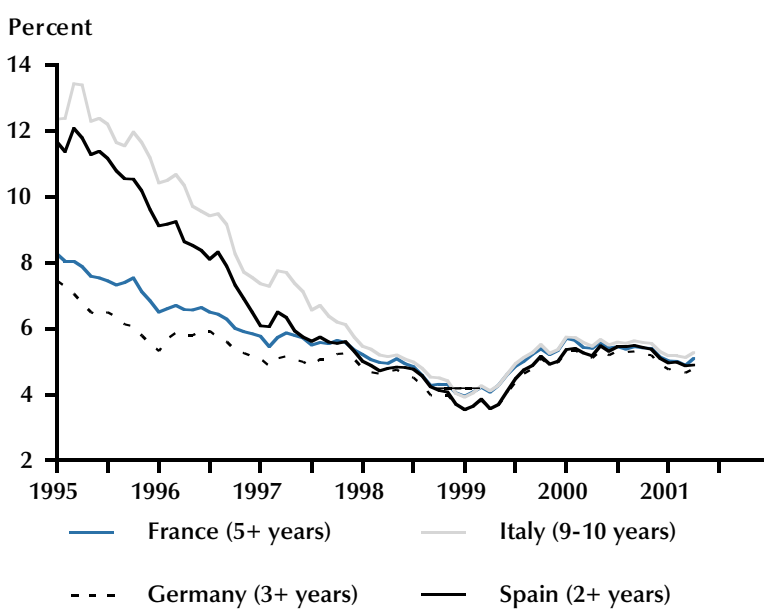

SOURCE: IMF, International Financial Statistics.

monetary union approached. Although differences remain, these are likely related to the lack of a common benchmark. As Figure 1 shows, there is no standard maturity structure for bonds in the euro area.

The euro-area government bond market thus does not present itself as a challenger to the U.S. market, which benefits from having a single issuerthe U.S. Treasury. In addition, in the United States, the Federal Reserve plays a role in the liquidity of the government bond market. ${ }^{17}$ Prati and Schinasi (1997) argue that the use of open market operations as the primary tool of monetary policy by the Federal Reserve "has fostered the development of efficient money and securities markets in the United States." Daily Federal Reserve activity in the securities market, they state, occurs not simply from a monetary policy objective but the desire to promote "the smooth functioning and stability of financial mar-

${ }^{14}$ For a discussion of developments in these markets, see European Central Bank (2000) and International Monetary Fund (1999).

${ }^{15}$ See Santillán et al. (2000) for an analysis of the effects of the euro on the money and bond markets in Europe.

${ }^{16}$ Unlike the trade data, international bond market data currently do not exclude cross-border transactions within the euro area.

${ }^{17}$ The recent reduction in the federal debt has raised concerns about the future liquidity of the U.S. Treasury market. See Fleming (2000) and Bennet et al. (2000) for a discussion of the effects of the decline in public debt and ways to maintain liquidity in the Treasury market. 


\section{Table 8}

Foreign Exchange Market Transactions Involving Select Currencies (Percent of Total) April 1998

\begin{tabular}{|c|c|c|c|c|c|c|}
\hline Category & U.S. dollar & Japanese yen & Deutsche mark & French franc & Euro area* & Pound sterling \\
\hline Spot & 78.8 & 24.7 & 42.7 & 3.3 & 56.8 & 11.6 \\
\hline Forwards & 81.4 & 26.7 & 28.0 & 5.1 & 50.7 & 12.3 \\
\hline Swaps & 95.2 & 16.7 & 20.0 & 6.5 & 48.8 & 10.2 \\
\hline Total & 87.4 & 20.8 & 29.8 & 5.1 & 52.2 & 11.0 \\
\hline
\end{tabular}

*Euro area includes the currencies of the current member countries plus the Danish krone and the ecu.

SOURCE: Bank for International Settlements, Central Bank Survey of Foreign Exchange and Derivatives Market Activity 1998. Basle: BIS, May 1999.

kets." Whereas, the infrequent interventions by individual European central banks in securities markets "tended to discourage the development of private securities markets and foster the predominance of bank-intermediated finance." The ECB has continued this practice of infrequent interventions. In general, it is active in securities markets only once per week.

For now U.S. financial markets continue to lead the world in both size and liquidity. As a result, the U.S. dollar remains the major currency in international bond markets. The euro, however, has already become a major player in these markets, and its use will likely expand as euro-area financial market integration proceeds. The development of a euro-area capital market similar to the U.S. market should provide benefits to both economies by increasing the options available to borrowers and lenders on both sides of the Atlantic.

\section{Vehicle Currency}

There are no direct data available on vehicle currencies, but this information can be gleaned from the shares of currencies in foreign exchange transactions, as shown in Table $8 .{ }^{18}$ In 1998 the dollar was involved in 87 percent of all currency exchanges. ${ }^{19}$ The euro legacy currencies were involved in 52 percent of all exchanges, with the Deutsche mark the most often traded of these currencies. The yen was used in 21 percent of all currency trades. The dollar's dominance was especially clear in forward and swap transactions. The dollar was involved in 81 percent of all forward trades compared with the mark's and yen's shares of 28 and 27 percent, respectively. In swaps the contrast was even greater. The dollar was involved in 95 percent of all swaps, with the mark and yen taking part in 20 and 17 percent, respectively, of all trades.

The use of the dollar in foreign exchange transactions was well above its use in international trade and debt contracts, indicating its role as a vehicle currency. The BIS (1999) notes that evidence of the dollar's role as a vehicle currency is provided by its use in seven of the ten most heavily traded currency pairs. The report also notes that it is standard practice for the dollar to be used as a vehicle currency in swaps, which explains the high percentage of swaps involving the U.S. dollar and the low use of the yen and mark in these trades.

The use of a currency as a vehicle currency is determined primarily by transactions costs. Transactions costs are inversely related to volume in each bilateral currency market. ${ }^{20}$ This volume is in turn determined by a currency's share in international trade and capital flows. Thus, the use of a currency in invoicing international trade, in international capital markets, and as a reserve currency lowers the transactions costs associated with the use of that currency.

A vehicle currency emerges whenever the indirect exchange costs through the vehicle are less than direct exchange costs between two non-vehicle currencies. For example, given the depth of the exchange market for dollars, it may be less costly

\footnotetext{
18 These data are gathered from a triennial survey of foreign exchange markets conducted by the BIS

${ }^{19}$ Since there are two currencies involved in an exchange, the total share of all currencies traded on international exchanges will equal 200 percent. However, a single currency can, at most, be involved in 100 percent of all exchanges.

20 The use of transactions cost theory to explain the rise of a vehicle currency was developed by Krugman (1980) and Chrystal (1984).
} 
to exchange Mexican pesos for U.S. dollars and then exchange U.S. dollars for Korean won rather than to exchange pesos directly for won. Indeed, the existence of transaction costs may reinforce the use of the dollar as an invoice currency.

The extent of liquidity in asset markets also affects the development of a vehicle currency. Banks prefer to hold most of their foreign currencies in the form of interest-earning assets rather than cash. The liquidity of these assets is a key determinant of the transactions costs involved in switching from one currency to another. Liquidity is determined not simply by the size of a country's capital markets but also by the extent to which secondary markets operate.

The prospects of the euro becoming an important vehicle currency thus depend primarily on the transactions costs associated with euro exchanges. Clearly the size of the euro currency market relative to the markets for individual euro currencies will result in lower relative transactions costs for the euro. These transactions costs will also depend on the extent to which the euro is adopted as (1) an invoice currency, (2) a reserve currency, and (3) a prevalent currency in international capital markets.

Preliminary data indicate that the euro has not increased its role as a vehicle currency to a level beyond that of the mark. According to the BIS (2000a), the market share of the euro in currency markets during 1999 was close to the share of the Deutsche mark in 1998. Indeed, because a vehicle currency is no longer needed to facilitate exchanges among the euro currencies, the use of the euro as a vehicle currency has probably declined relative to that of the mark. Evidence on the limited use of the euro as a vehicle currency is also provided by data from foreign exchange markets in emerging market countries. The use of the euro in these markets during 1999 was concentrated in Eastern Europe, again similar to that of the mark in 1998. In Thailand and Korea for example, the euro was involved in less than 1 percent of local currency trades (BIS 2000a).

\section{Substitute Currency}

Another role that an international currency may play is as a substitute for domestic-currency transactions. Uncertainty surrounding the purchasing power of a domestic currency can lead to the use of a foreign currency as a unit of account, store of value, and medium of exchange in the domestic economy. This generally occurs as a result of hyperinflation and/or political instability.
In the decades prior to the creation of the euro, the dollar and the mark were the only currencies used extensively outside their respective borders, with the dollar being the predominate substitute currency. In part, this predominance of the dollar was a result of the links between the United States and countries using a substitute currency. Nevertheless, the ease of availability of the dollar, which both determines and encourages its other uses as an international currency, continues to facilitate the use of the dollar as a substitute currency.

Measures of the extent to which currencies are used as substitute currencies are not easily obtained. However, the best estimates indicate that about 55 percent of the total U.S. currency held by the nonbank public was held abroad at the end of $1995 .{ }^{21}$ About 35 percent of Deutsche mark holdings were abroad (Seitz, 1995).

The use of the U.S. dollar as a substitute currency began in earnest in the 1920s as a result of hyperinflations in several European countries. ${ }^{22}$ Its use in Latin America expanded in the 1980s also as a result of hyperinflation. Most recently, the collapse of the Soviet Union expanded the use of the dollar in that region. ${ }^{23}$ Although the dollar is the preferred substitute currency in the former Soviet Union, the German mark is more prevalent in some Eastern European countries as well as in the former Yugoslav republics.

The use of the dollar as a substitute currency provides a direct benefit to the United States through seigniorage earnings. These earnings are generally estimated by calculating the amount the U.S. government would have to pay if, rather than holding cash, individuals in these countries held U.S. Treasury securities. The top panel of Figure 2 provides a rough estimate of the real seigniorage earned by the United States as a result of foreign holdings of U.S. currency during the period 1973-99.24 In real terms, seigniorage revenues have averaged $\$ 8.7$

21 See Anderson and Rasche (2000) and Porter and Judson (1996). According to Anderson and Rasche, the share of U.S. currency held abroad increased throughout the 1970s and 1980s but fell slightly in the 1990 s

22 The dollar was preferred to the British pound as the latter had yet to return to the gold standard after World War I.

23 According to the U.S. Treasury (2000), Argentina and Russia are believed to have the largest holdings of U.S. currency outside the United States.

${ }^{24}$ These seigniorage revenues are estimated by using the interest rate on one-year Treasury bills and adjusting nominal revenues using the GDP deflator. 


\section{Figure 2}

\section{Seignorage Revenues from Foreign Holdings of U.S. Dollars}

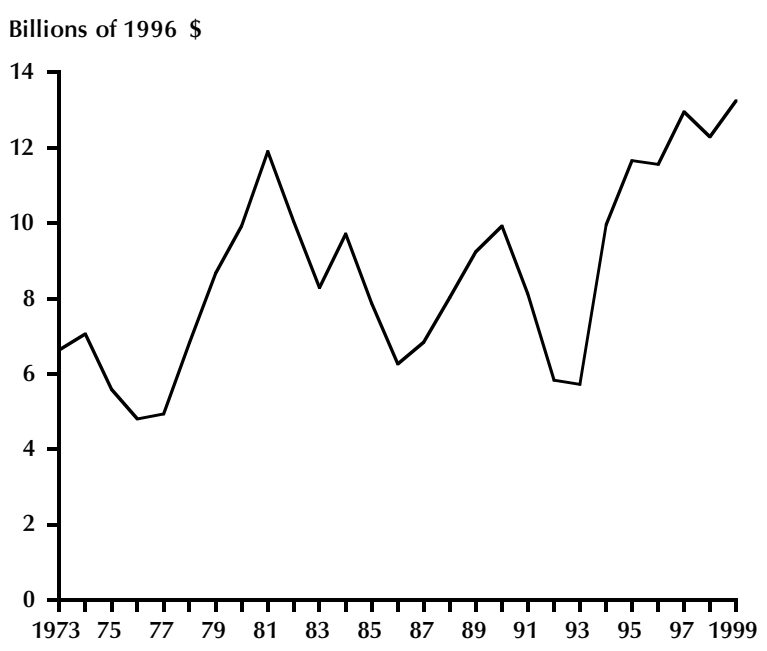

Percent of federal government expenditures

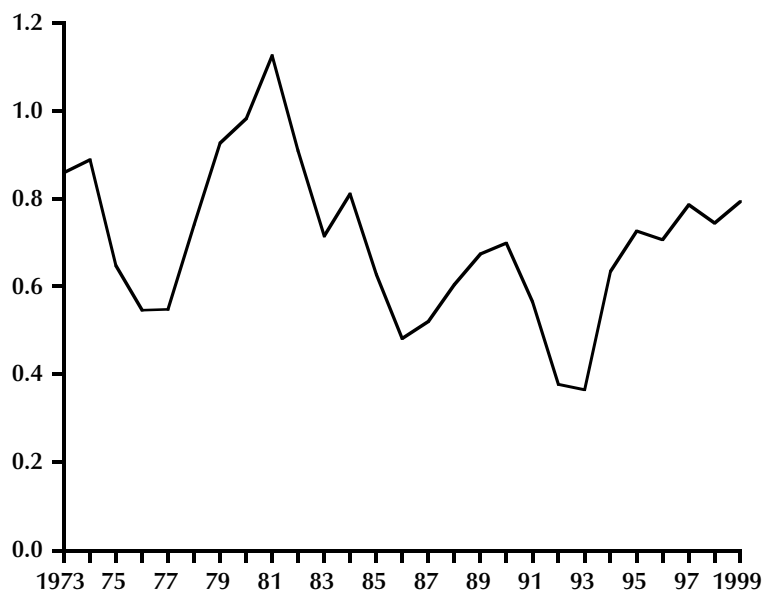

SOURCE: Department of Commerce, Bureau of Economic Analysis, and Board of Governors of the Federal Reserve System.

billion on a yearly basis over this period. One method of estimating the importance of these seigniorage revenues is to calculate the share of government expenditures accounted for by these revenues. This is shown in the bottom panel of Figure 2. On average less than 1 percent of the expenditures of the U.S. federal government have been financed by seigniorage revenues on currency held abroad. 25

The euro is not likely to rapidly replace the dollar as the substitute currency of choice. In fact, the use of the euro as a substitute currency is likely to lag behind its use as an international currency. Foreign holders of a substitute currency want a stable, secure currency. Uncertainty surrounding the value of the euro, particularly given its decline against the dollar during the first two years of its existence, will limit the near-term attractiveness of the euro as a substitute currency.

If the euro does become increasingly used as a substitute currency, the seigniorage earnings of the ECB will rise. It is difficult to predict how large these revenues might be, as they depend on the world demand for substitute currencies, the shares of the euro and the dollar, and interest rate conditions. Emerson et al. (1992) estimated that these seigniorage revenues would, at most, amount to $\$ 2.5$ billion a year for the ECB.

\section{THE OFFICIAL USES OF AN INTERNATIONAL CURRENCY}

\section{Exchange Rate Peg}

Under the Bretton Woods system that existed from 1946 to 1973, most currencies in the world were tied to the U.S. dollar. With the demise of the Bretton Woods system, many countries chose to let their currencies float while others set the value of their currency against that of another country. Of those countries choosing the latter option, most continued to peg their currency to the U.S. dollar. In 1975, 52 members countries (about 41 percent) of the International Monetary Fund (IMF) pegged their currency to the dollar, as shown in Table 9. The euro legacy currencies were the second most popular choice. The French franc was the peg for the African Financial Community (CFA) franc, the currency used by the then 13 members of the CFA; and the Spanish peseta was the exchange rate peg for the currency of Equatorial Guinea. The pound was the only other European Union currency to be used as an exchange rate peg.

Over time the popularity of currency pegs has declined. However, both the number and percentage of member countries pegging their currencies to the euro have risen. In 2000, 24 IMF member countries tied their currencies to the euro. ${ }^{26}$ The 14

\footnotetext{
25 The seigniorage benefits must be weighed against the problems the foreign holdings of currency create for monetary policy. As Porter and Judson (1996) note, if foreign demand for a country's currency is unrelated to domestic demand, then the interpretation of movements in monetary aggregates becomes more difficult.

26 These 24 include San Marino, which uses the Italian lira as its currency, and Greece, which is now a member of the euro area.
} 
FEDERAL RESERVE BANK OF ST. LOUIS

\section{Table 9}

\section{Currency Pegs}

\begin{tabular}{|c|c|c|c|c|c|c|}
\hline \multirow[b]{2}{*}{ Year } & \multicolumn{2}{|c|}{ U.S. dollar } & \multicolumn{2}{|c|}{ Euro currencies } & \multicolumn{2}{|c|}{ Other E.U. } \\
\hline & Number & Percent & Number & Percent & Number & Percent \\
\hline 1975 & 52 & 40.6 & 14 & 10.9 & 8 & 6.3 \\
\hline 1980 & 39 & 27.7 & 15 & 10.6 & 1 & 0.7 \\
\hline 1985 & 31 & 20.8 & 14 & 9.4 & 1 & 0.7 \\
\hline 1990 & 25 & 16.2 & 15 & 9.7 & 0 & 0.0 \\
\hline 1995 & 22 & 12.2 & 17 & 9.4 & 0 & 0.0 \\
\hline 2000 & 23 & 12.6 & 24 & 13.2 & 0 & 0.0 \\
\hline
\end{tabular}

SOURCE: IMF, Annual Report on Exchange Arrangements and Exchange Restrictions, various issues.

CFA members continue to constitute the majority of countries whose currencies are tied to the euro. Most of the remaining 10 countries whose currencies are pegged to the euro hope to be in the first or second wave of enlargements of the European Union. In addition, Denmark, which is one of the three members of the European Union who are not currently members of the euro area, ties its currency to the euro through the Exchange Rate Mechanism (ERM) II. ${ }^{27}$

According to these data, the U.S. dollar is now the second most popular choice for a currency peg, with 23 countries officially tying their currencies to the dollar. ${ }^{28}$ In practice, however, the dollar remains the currency against which most countries limit movements in their domestic currencies. For example, 20 countries in addition to those listed in Table 9 strictly limit the movement of their domestic currencies against the dollar. Some of these currencies are officially tied to another currency. Jordan, for example, officially pegs its currency to the SDR but in practice pegs to the U.S. dollar.

The primary reason countries choose to peg their currency to another currency is to reduce exchange rate risk and/or to control inflation. Keeping the currency stable against the peg, or setting limits on exchange rate changes, minimizes the risk to those borrowing or lending in foreign currencies or engaged in international trade. The unexpected failure of a currency peg, however, can produce sharp changes in the exchange value of the local currency and lead to losses on contracts priced in foreign currencies. Partly as a result, pegs have become less popular over the last 30 years.

For those countries who do peg, the currency choice is usually determined by trade and financial links. This explains why, among countries with currency pegs, Latin American and Caribbean countries are pegged to the dollar while most European and African countries peg to the euro. Likewise, because oil is priced in dollars on world markets, many oil exporting countries either officially or in practice limit the fluctuations of their currency against the dollar.

The introduction of the euro has not resulted in any countries shifting their peg from the dollar to the euro. Nonetheless, it is likely that the share of currencies pegged to the euro will rise as more of the countries hoping to be admitted to the European Union may peg their currencies to the euro. In addition, any European Union country wanting to enter the euro area will have to first peg to the euro.

Any effect on the euro area and the United States caused by an increase in the number of countries pegging their currencies to the euro relative to those pegging to the dollar will occur through the effects of these pegs on foreign currency reserves.

\section{Reserve Currency}

In 1973 the dollar accounted for 76.1 percent of the official foreign currency reserves held by the

\footnotetext{
${ }^{27}$ Established in 1979, ERM was the fixed exchange rate system of the European Monetary System. With the creation of the euro, ERM was replaced by ERM II, linking the currencies of Denmark and Greece (until January 2001) to the euro.

${ }^{28}$ These 23 include five countries (Ecuador, Marshall Island, Micronesia, Palau, and Panama) that use the U.S. dollar as the local currency. In January 2001, El Salvador (which is not included in the 23) also adopted the U.S. dollar
} 


\section{Figure 3}

\section{Currency Composition of Foreign Exchange Reserves}
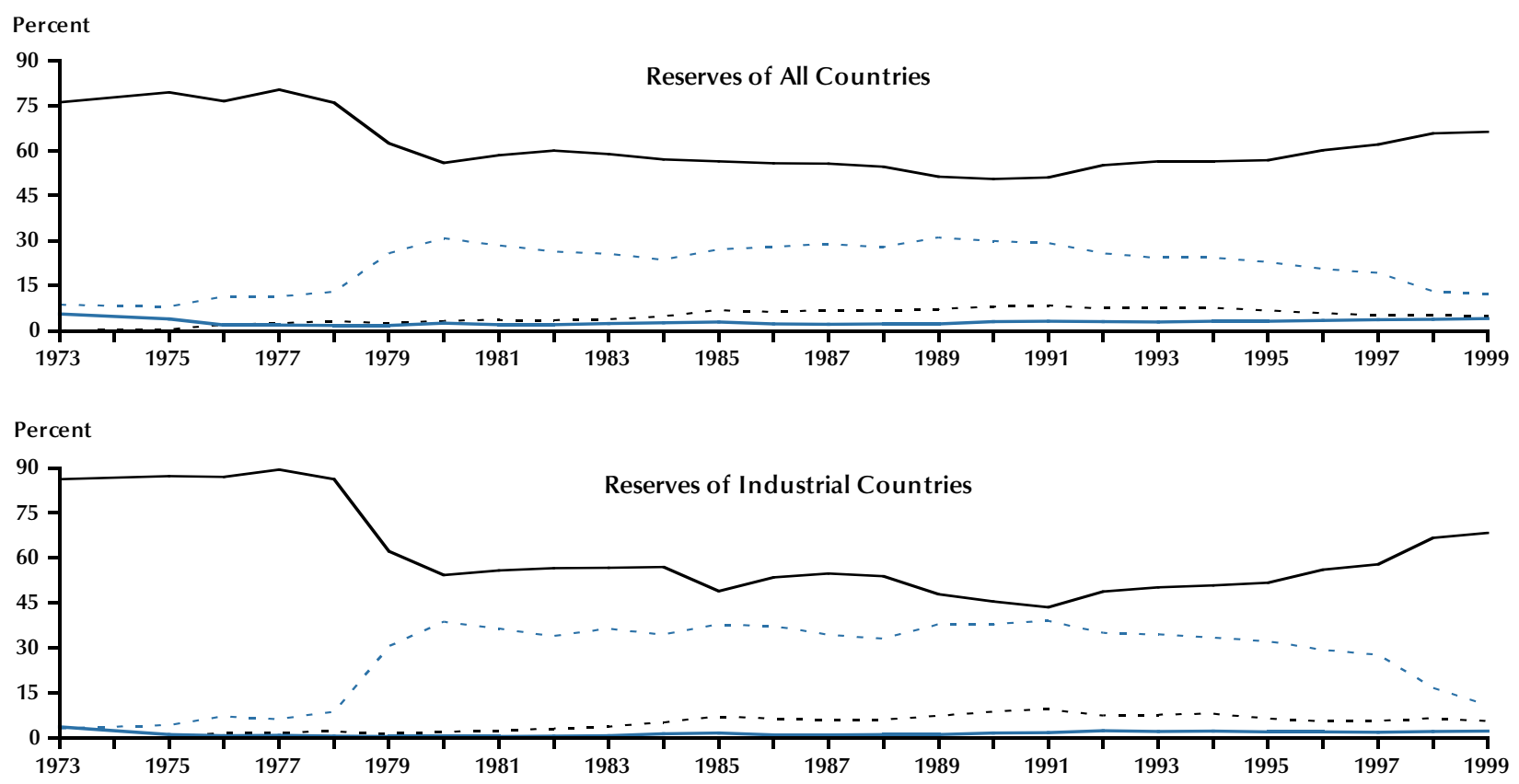

Percent

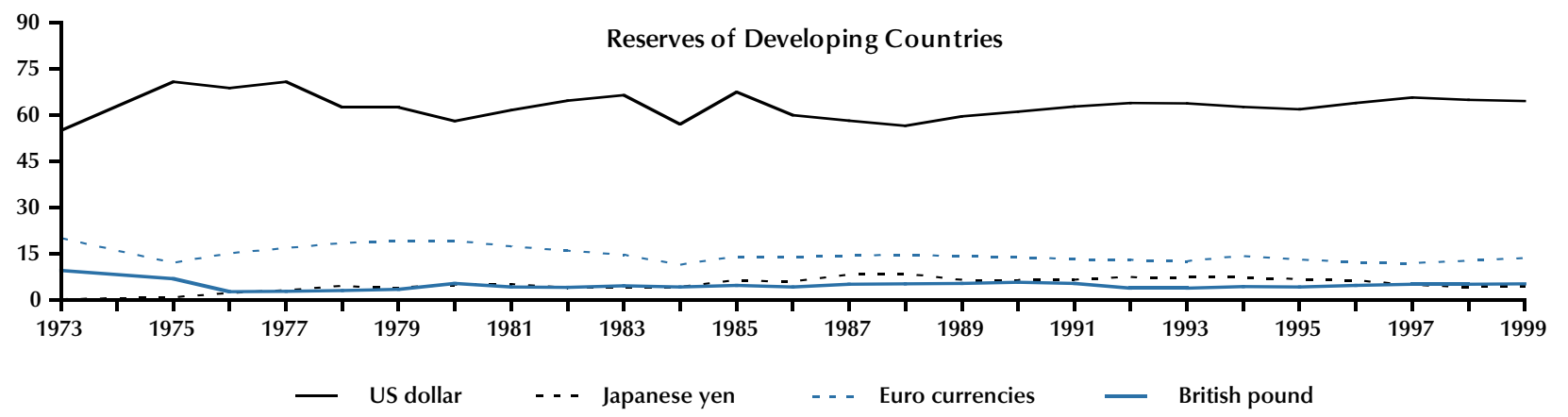

SOURCE: IMF, Annual Report (various years).

member countries of the IMF, as shown in the top panel of Figure 3. The euro legacy currencies had an 8.7 percent share of foreign currency reserves, and the pound sterling had a 5.6 percent share. Holdings of yen were only 0.1 percent of total reserves.

The dollar's share in foreign currency reserves declined in the late 1970s as some countries diversified their holdings, shifting primarily into euro legacy currencies, particularly Deutsche marks. Although the dollar's share fell again in the late 1980s, it has increased somewhat since 1991 to stand at 66.2 percent in 1999.29 The share of the euro currencies peaked in 1989 at 31.1 percent and has fallen steadily since then, standing at 12.5 percent in 1999. The share of the yen rose slowly through most of the 1970s and 1980s, reaching a peak of 8.5 percent in 1991. Since then the yen's share has fallen, reaching 5.1 percent in 1999.

\footnotetext{
29 These shifts in holdings of reserves are affected both by changes in the physical holdings of currency and changes in exchange rates. Since the IMF measures reserve holdings in U.S. dollars, a rise in the exchange value of the dollar ceteris paribus will raise the dollar share of foreign exchange reserves.
} 


\section{Table 10}

\section{Currency Composition of Long-Term Debt in Developing Countries (Percent)}

\begin{tabular}{lrrrr} 
Currency & $\mathbf{1 9 7 0}$ & $\mathbf{1 9 8 0}$ & $\mathbf{1 9 9 0}$ & $\mathbf{1 9 9 9}$ \\
\hline U.S. dollar & 47.1 & 49.8 & 41.2 & 56.0 \\
Japanese yen & 2.3 & 6.9 & 10.5 & 12.6 \\
Euro-area currencies & 13.8 & 12.1 & 14.3 & 9.3 \\
Pound sterling & 11.2 & 3.4 & 2.3 & 1.2 \\
Multiple currencies & 11.6 & 10.9 & 14.7 & 8.2 \\
Other currencies & 14.0 & 16.9 & 17.0 & 12.7
\end{tabular}

SOURCE: World Bank, Global Development Finance, 2001.

In the 1970s the developing countries, as a group, had more diversified holdings of foreign currencies than did the industrial countries, as shown in the middle and lower panels of Figure 3. Throughout most of the 1980s and 1990s, however, the developing countries held a greater share of their reserves in dollars than did the industrial countries. Currently there is little difference in the currency composition of reserves across developing and industrial countries. These changes can be explained by examining why countries hold reserves. Governments and central banks hold reserves for three main purposes: (i) to finance imports; (ii) to finance foreign debt; and (iii) to intervene in currency markets to manage the exchange rate. ${ }^{30}$ In advanced economies, private markets generally fulfill the role of financing trade and debt. Hence, reserves are held primarily for intervention purposes.

In developing countries all three purposes are important. The currencies in which imports are invoiced in developing countries is a key determinant of the composition of reserves. Similarly, because reserves also are important for financing foreign debt, the currency composition of this debt will affect the currency composition of reserves. As shown in Table 10, the long-term debt of developing countries is most commonly denominated in U.S. dollars.

Euro-area currencies are the next preferred choice, but this share has declined slightly over the past 30 years. Most noticeable has been the decline in the use of the pound in debt contracts of developing countries. This decline is partly reflected in the relative fall in pound reserves held by developing countries. In contrast, the rise in use of the yen in debt contracts between 1970 and 1990 is reflected in the rise in yen foreign exchange reserves.

The currency choice of reserves for intervention purposes depends in part on a country's exchange rate regime. Heller and Knight (1978) showed that, if a country pegged its exchange rate to a particular currency, that currency's share in its reserves rose. Dooley et al. (1989) showed that industrial economies with flexible exchange rates had a high share of dollar reserves and a low share of Deutsche mark reserves. Among industrial economies, the main fixed exchange rate regime was the ERM. The establishment of the ERM in 1979 coincides with the sharp rise in the share of euro legacy currencies (particularly marks) in the foreign currency reserves of industrial economies. ${ }^{31}$ The importance of the exchange rate arrangement in determining the currency composition of a country's reserves is linked to the use of these reserves for intervening in the currency markets.

The risk and return on currencies is also a factor in determining the currency composition of reserves. Most reserves are held in the form of government securities. Thus, changes in the relative return on these securities in conjunction with the depreciation risk, particularly if sustained over a long period, may cause shifts in a country's composition of reserves. In addition, the liquidity of government securities markets is a factor in determining the choice of reserve currency because reserves may need to be sold quickly for intervention purposes.

\footnotetext{
30 See Ben-Bassat (1980, 1984) and Dooley et al. (1989).

31 Data in Masson and Turtelboom (1997) indicate that the European Union countries held 69 percent of the Deutsche mark reserves held by industrial countries in 1995 .
} 
What has been the initial effect of the creation of the euro on the currency composition of reserves? As Figure 3 indicates, the dollar's share has risen and the euro's share has fallen. This occurred for two reasons: the elimination of ecu reserves and the reclassification of intra-euro-area holdings of euro currency reserves. ${ }^{32}$ At the end of 1997, ecu reserves accounted for 10.7 percent of the foreign currency reserves of industrial countries and 5.0 percent of the reserves of all countries. Most of these ecu reserves were claims on the European Monetary Institute, the precursor to the European Central Bank. They had been issued to the central banks of the European Union countries in exchange for gold and dollar deposits. In late 1998 the deposits were returned to these central banks and the ecu reserves were eliminated. This explains the sharp drop in euro legacy currency reserves in the industrial countries in 1998. With the advent of the euro in 1999, holdings by euro-area countries of the euro legacy currencies ceased to be foreign currency reserves. This led to a further decline in the share of the euro in the foreign currency reserves of industrial countries.

The importance of the transition to the euro in driving movements in the currency composition of worldwide reserves over the last two years is further indicated by looking at the developing countries. As the bottom panel of Figure 3 indicates, the euro share of reserves held by developing countries rose slightly in the last few years. In 1997 the euro legacy currencies accounted for 12 percent of the reserves of developing countries. At the end of 1999, the euro accounted for 13.6 percent of their reserves. Thus, while there is no evidence that the creation of the euro has led to a drop in the relative holdings of euros outside the euro area, neither is there evidence of a marked rise in these holdings.

The lack of a noticeable shift in the composition of world reserves is not surprising. The trade and debt financing needs of the developing countries remain primarily in dollars. Certainly, as the euro's use as an international medium of exchange rises, countries are likely to increase their holdings of euro reserves. It is also unlikely that the creation of the euro has had a noticeable effect on the demand for reserves for intervention purposes. ${ }^{33}$ Central banks are unlikely to sell much of their dollar holdings to buy euros without good cause. The ECB notes "central banks traditionally refrain from abrupt and large changes in the level and composition of their foreign reserves" (ECB, 1999, p. 41). Johnson (1994) argues that as long as the Federal Reserve achieves an acceptable degree of price stability in the United States, changes in reserve holdings should occur gradually.

The implications of a shift in international reserves away from the U.S. dollar and toward the euro depend on the speed at which such a change would occur. A massive sale of dollars by central banks and the purchase of euros would cause a sharp drop in the value of the dollar relative to the euro. This shift would also raise interest rates on U.S. government securities since, as noted above, most reserves are held in government securities. In contrast, the euro would rise in value and interest rates in the euro area would drop. As discussed above, this scenario is improbable. The ECB (1999) asserts that portfolio shifts are "expected to take place at a slower pace in the central bank community than in the private sector." Indeed, despite concerns with the euro area over the decline in the foreign exchange value of the euro, the national central banks have not sold noticeable amounts of their substantial holdings of dollar reserves. ${ }^{34}$

A gradual shift in international reserves toward the euro is unlikely to have much effect on the United States or the euro area. Because nearly all international reserves are invested in government securities, the reserve currency country does not gain any seigniorage benefits. The most important benefit is the possibility that reserve currency status lowers the interest rate at which the government can borrow. Thus, it is argued that the euro area will benefit through a reduction in the interest rate at which governments can borrow while the U.S. government will see its borrowing costs rise.

A negative interest rate effect on the United States would require not simply a rise in the share

\footnotetext{
32 The ecu, or more formally, European currency unit, was a weighted average of the European Union currencies. Although it never existed as a paper currency, it was used as the unit of account for official European Union activities and a small ecu private bond market existed The ecu was superceded by the euro.

33 Hong Kong, however, announced in late 1999 that it was increasing the share of the euro in its foreign currency reserves.

34 The national central banks transferred a small portion of their reserves to the ECB upon its creation but kept most of the remaining reserves. As of September 2000, the foreign exchange reserves of the ECB were $\$ 43.7$ billion while the reserves of the national central banks were $\$ 212.2$ billion. In contrast, the United States held $\$ 31.2$ billion in foreign exchange reserves. Although the national central banks may have wanted to hold on to their reserves to handle any possible crisis in the early years of the euro, the available pool of reserves is more than sufficient to handle any problems.
} 
of reserves held in euros, but an absolute decline in holdings of dollar reserves. Given the trends in the growth of worldwide reserves, the latter change will take longer (if ever) to occur than the former. In addition, the extent of the interest rate benefit to a reserve currency is not well established. Blinder (1996) is skeptical of the importance of such a link. He argues that if such a benefit were significant then there should be a larger difference between interest rates on government and corporate bonds in the United States than in other major countries; yet he finds no evidence to support this argument. The euro area is more likely to see a fall in government borrowing costs from measures to standardize government bond markets than through an increase in the use of the euro as a reserve currency (BIS, 2000b).

\section{Intervention Currency}

A corollary to the dollar's role as the primary international reserve currency is its use as the main currency for intervening in foreign exchange markets. This latter role is also aided by the use of the dollar as a vehicle currency and by the liquidity of the U.S. bond market, as discussed earlier in this article. Although data on interventions are limited, it is believed that nearly all intervention in the currencies markets, with the exception of those undertaken by the United States, takes place in dollars. ${ }^{35}$

The most important determinants of the choice of intervention currency are liquidity and acceptability. In countries that peg their exchange rate, the currency peg will determine the intervention currency. Since countries prefer to hold their reserves in the form of interest-earning assets, the liquidity of these assets is extremely important. The relative illiquidity of the euro-area and Japanese bond markets gives the dollar an advantage over the use of these two currencies. ${ }^{36}$

The acceptability of an international currency is related to its role as a medium of exchange for private transactions. The more frequently a currency is used for private transactions the larger is the exchange market for that currency, which increases the ease with which a country can use the currency for intervention purposes.

\section{CONCLUSION}

Factors determining whether a country's currency will be used readily outside its border include the size and openness of its economy and financial markets as well as its macroeconomic policy environment. In the postwar period, these factors have favored the use of the U.S. dollar as the predominant international currency. In the early postwar period, there were few alternatives to the dollar in international markets as a result of restrictions on convertibility and limits on capital mobility. In the last several decades, as other major economic powers emerged (notably Germany and Japan) and markets opened, the dollar's dominance has been reduced. Nonetheless, the dollar has remained the most important international currency.

On January 1, 1999, the euro was created, linking an economic area nearly the size of the U.S. economy. The euro's impact will be felt in markets throughout the world economy. For the first time the dollar faces a potential challenge to its role as the world's major international currency.

In the first two years of its existence, the euro's presence has been felt most in international securities markets. Issues of euro-denominated foreign bonds surged in 1999. The euro legacy currencies accounted for 28.0 percent of new bond issues in 1998. The share of new issues denominated in euros was 38.3 percent in 1999. In international money markets, the euro's presence was even more obvious. International money market instruments denominated in euros in 1999 accounted for 32.9 percent of the market, well above the 17.2 percent share of the legacy currencies in 1998. Although the euro's share of international debt securities declined in 2000 , the euro continues to be a widely used alternative to the dollar in these markets. Little change, however, has occurred in the use of the euro relative to the dollar in the other functions of an international currency.

In the short-term there is unlikely to be much change in this pattern. Over time, however, the use of the euro relative to the dollar will likely increase, particularly as euro-area financial markets become more integrated and more liquid. Nevertheless, the decline in the dollar's share and the rise in the euro's share in international transactions is likely to occur gradually. In part, this is because the more often a currency is used in international transac-

\footnotetext{
${ }^{35}$ Under the rules of the ERM, mandatory interventions (when the exchange rate reached its upper or lower limit) had to take place in one of the member currencies. Non-mandatory (intra-band) interventions could take place in any currency, and generally dollars were used. See Giavazzi (1989) for details.

${ }^{36}$ The existence of swap arrangements between central banks can offset some of these liquidity problems.
} 
tions, the lower are the costs associated with using that currency and hence the more attractive is the currency for conducting international exchanges. Thus, there is much inertia in the choice of an international currency. The British pound, for example, continued to play a major role as an international currency long after its dominance of the global economy waned.

Policies on the part of the governments and central banks in the euro area and the United States will play a crucial role in the use of their currencies in international markets. The ability of the euroarea governments to foster sustained economic growth in the region is important. Equally important is the credibility of the ECB. The ability of the ECB to maintain a low inflationary environment in the euro area is a key factor in determining the use of the euro outside the region. In addition, concerns about the attachment of European governments and the public to a monetary union will undermine the use of the euro in international markets.

The ultimate determinants of the continued use of the dollar as an international currency are the economic policies and conditions in the United States. As Lawrence Summers noted when he was Deputy Secretary of the U.S. Treasury, "Ultimately, the dollar's relative standing in the international financial system will always depend more on developments here than on events elsewhere" (Summers, 1997). In the absence of an economic crisis in the United States, the dollar is not likely to lose its standing as the most popular international currency.

Any shifts in the roles of the dollar and euro will affect both the United States and the European Union. The extent to which a country benefits from having its currency used internationally is not clear. The use of a currency for invoicing may reduce the costs borne by that country's importers, but these costs may be small at best. The use of a currency as a reserve currency may reduce the borrowing costs of that country's government, but again the extent of this benefit is not known. The use of a currency as a substitute currency does provide seigniorage benefits but also complicates monetary policy. Moreover, if these seigniorage revenues arise as a result of an economic and/or political instability, the benefit to the country earning the seigniorage may be more than offset by the costs of the instability.

The creation of the euro has the potential to produce benefits to both the United States and the euro area that could far outweigh the effects of any shifts in international currency holdings. Developments in European financial markets alone should increase the investment options available to consumers as well as reduce the costs of borrowing for businesses. These developments will benefit those on both sides of the Atlantic.

\section{REFERENCES}

Anderson, Richard G. and Rasche, Robert H. "The Domestic Adjusted Monetary Base.” Working Paper 2000-002A, Federal Reserve Bank of St. Louis, January 2000.

Bank for International Settlements. BIS Quarterly Review. Basle: BIS, February 2000a. 70th Annual Report. Basle: BIS, June 2000b. Central Bank Survey of Foreign Exchange and Derivatives Market Activity 1998. Basle: BIS, May 1999.

Bekx, Peter. "The Implications of the Introduction of the Euro for Non-EU Countries." Euro Papers Number 26, European Commission, Directorate General Economic and Financial Affairs, July 1998.

Ben-Bassat, Avraham. "The Optimal Composition of Foreign Exchange Reserves.” Journal of International Economics, May 1980, 10(2), pp. 285-95.

"Reserve-Currency Diversification and the Substitution Account." Princeton Studies in International Finance, 1984, (53).

Bénassy, Agnès and Deusy-Fournier, Pierre. "Competition Among the World's Dominant Currencies Since Bretton Woods Collapsed." Unpublished manuscript, Centre for International Economics (CEPII), Paris, April 1994.

Bénassy-Quéré, Agnès; Mojon, Benoît and Schor, ArmandDenis. "The International Role of the Euro." Working Paper 98/03, CEPII, July 1998.

Bennett, Paul; Garbade, Kenneth and Kambhu, John. "Enhancing the Liquidity of U.S. Treasury Securities in an Era of Surplus.” Federal Reserve Bank of New York Economic Policy Review, April 2000, 6(1), pp. 89-119.

Bergsten, C. Fred. "The Dollar and the Euro." Foreign Affairs, July/August 1997, 76(4), pp. 83-95.

Black, Stanley W. "The International Use of Currencies," in Yoshi Suzuki, Junichi Miyake, and Mitsuaki Okabe, eds., The Evolution of the International Monetary System: How 
Can Efficiency and Stability Be Achieved? Tokyo: University of Tokyo Press, 1990.

Blinder, Alan S. "The Role of the Dollar as an International Currency.” Eastern Economic Journal, Spring 1996, 22(2), pp. 127-36.

Cecchetti, Stephen G. "Legal Structure, Financial Structure, and the Monetary Policy Transmission Mechanism." Working Paper No. 7151, National Bureau of Economic Research, June 1999.

Chrystal, K. Alec. "On the Theory of International Money," in John Black and Graeme S. Dorrance, eds., Problems of International Finance. New York: St. Martin's Press, 1984.

Cohen, Benjamin J. The Future of Sterling as an International Currency. London: Macmillian Press, 1971.

Dooley, Michael P.; Lizondo, J. Saul and Mathieson, Donald J. "The Currency Composition of Foreign Exchange Reserves." IMF Staff Papers, June 1989, 36(2), pp. 385-434.

Emerson, Michael; Gros, Daniel; Italianer, Alexander; Pisani-Ferry, Jean and Reichenbach, Horst. One Market, One Money: An Evaluation of the Potential Benefits and Costs of Forming an Economic and Monetary Union. Oxford: Oxford University Press, 1992.

European Central Bank. "The Euro Area One Year After the Introduction of the Euro: Key Characteristics and Changes in the Financial Structure." ECB Monthly Bulletin, January 2000, pp. 35-49.

. "The International Role of the Euro." ECB Monthly Bulletin, August 1999, pp. 31-53.

Fleming, Michael J. “The Benchmark U.S. Treasury Market: Recent Performance and Possible Alternatives.” Federal Reserve Board of New York Economic Policy Review, April 2000, pp. 129-45.

Giavazzi, Francesco. "The European Monetary System: Lessons from Europe and Perspectives in Europe." Economic and Social Review, January 1989, 20(2), pp. 73-90.

Grassman, Sven. "A Fundamental Symmetry in International Payments Patterns." Journal of International Economics, May 1973, 3(2), pp. 105-16.

Hartmann, Philipp. "The Future of the Euro as an International Currency: A Transactions Perspective.”
London School of Economics Financial Markets Group Special Papers, November 1996.

Heller, H. Robert and Knight, Malcom. "Reserve-Currency Preferences of Central Banks." Princeton Essays in International Finance, December 1978, (131).

International Monetary Fund. "Progress with European Monetary." International Capital Markets: Developments, Prospects, and Key Policy Issues, September 1999.

Johnson, Karen H. "International Dimension of European Monetary Union: Implications for the Dollar.” International Financial Discussion Paper No. 469, Board of Governors of the Federal Reserve System, May 1994.

Kenen, Peter B. "EMU, Exchange Rates and the International Monetary System." Recherches Economiques de Louvain, 1993, 59(1/2), pp. 257-81.

Kool, Clemens J.M. "International Bond Markets and the Introduction of the Euro," Federal Reserve Bank of St. Louis Review, September/October 2000, 82(5), pp. 41-56.

Kregel, Jan A. "Can European Banks Survive a Unified Currency in a Nationally Segmented Capital Market?" Working Paper No. 305, Jerome Levy Economics Institute, July 2000.

Krugman, Paul. "Vehicle Currencies and the Structure of International Exchange." Journal of Money, Credit and Banking, August 1980, 12(3), pp. 513-26.

Laxton, Douglas and Prasad, Eswar. "Possible Effects of European Monetary Union on Switzerland: A Case Study of Policy Dilemmas Caused by Low Inflation and the Nominal Interest Rate Floor.” Working Paper WP/97/23, International Monetary Fund, March 1997.

Magee, Stephen, P. and Rao, Ramish K.S. "Vehicle and Nonvehicle Currencies in International Trade." American Economic Review, May 1980, 70(2), pp. 368-73.

Masson, Paul R. and Turtelboom, Bart G. "Characteristics of the Euro, the Demand for Reserves, and Policy Coordination Under EMU.” Working Paper No. 97/58, International Monetary Fund, May 1997.

Page, S. "The Choice of Invoicing Currency in Merchandise Trade." National Institute Economic Review, November 1981, 85, pp. 60-72. 
Pollard, Patricia S. "The Role of the Euro as an International Currency." The Columbia Journal of European Law, Spring 1998, pp. 395-420.

Porter, Richard D. and Judson, Ruth A. "The Location of U.S. Currency: How Much Is Abroad?" Federal Reserve Bulletin, October 1996, 82(10), pp. 883-903.

Portes, Richard and Rey, Hélène. "The Emergence of the Euro as an International Currency," in EMU: Prospects and Challenges for the Euro. Oxford: Blackwell Publishers, 1998.

Prati, Alessandro and Schinasi, Garry J. "European Monetary Union and International Capital Markets: Structural Implications and Risks.” Working Paper No. 97/62, International Monetary Fund, May 1997.

Santillán, Javier; Bayle, Marc and Thygesen, Christian.
"The Impact of the Euro on Money and Bond Markets." Occasional Paper No. 1, European Central Bank, July 2000.

Seitz, Franz. "The Circulation of Deutsche Mark Abroad." Discussion Paper No. 1/95, Economic Research Centre of the Deutsche Bundesbank, May 1995.

Summers, Lawrence H. Testimony Before the Senate Budget Committee, 21 October 1997.

Tavlas, George. "The International Use of the U.S. Dollar: An Optimum Currency Area Perspective." The World Economy, September 1997, 20(6), pp. 709-47.

United States Treasury Department and the Board of Governors of the Federal Reserve System. The Use and Counterfeiting of United States Currency Abroad. Washington D.C.: February 2000. 